\title{
Methanotorris formicicus sp. nov., a novel extremely thermophilic, methane-producing archaeon isolated from a black smoker chimney in the Central Indian Ridge
}

\author{
Ken Takai, ${ }^{1}$ Ken H. Nealson ${ }^{1,2}$ and Koki Horikoshi ${ }^{1}$ \\ ${ }^{1}$ Subground Animalcule Retrieval (SUGAR) Project, Frontier Research System for \\ Extremophiles, Japan Marine Science \& Technology Center, 2-15 Natsushima-cho, Yokosuka \\ 237-0061, Japan \\ ${ }^{2}$ Department of Earth Sciences, University of Southern California, 3651 Trousdale Pkwy, \\ Los Angeles, CA 90089-0740, USA
}

\begin{abstract}
A novel extremely thermophilic, methane-producing archaeon was isolated from a black smoker chimney at the Kairei field in the Central Indian Ridge. Cells of this isolate were irregular cocci with several flagella; motility was not observed. Growth was observed between 55 and $83^{\circ} \mathrm{C}$ (optimum of $75^{\circ} \mathrm{C} ; 30$ min doubling time) and between $\mathrm{pH} 6.0$ and 8.5 (optimum of $\mathrm{pH} 6 \cdot 7$ ). The isolate was a strictly anaerobic, methanogenic autotroph capable of using hydrogen and carbon dioxide as sole energy and carbon sources. Formate was utilized as an alternative energy source. The $\mathrm{G}+\mathrm{C}$ content of the genomic DNA was $33.3 \mathrm{~mol} \%$. Phylogenetic analysis based on $16 \mathrm{~S}$ rRNA gene sequences indicated that the isolate was most closely related to Methanotorris igneus strain $\mathrm{Kol} 5^{\top}$. The isolate, however, could be genetically differentiated from this species by DNA-DNA hybridization analysis and on the basis of its physiological properties. The name Methanotorris formicicus sp. nov. is proposed for this isolate; the type strain is Mc-S-70 $\left(=\mathrm{JCM} 11930^{\top}=\right.$ ATCC BAA-687 $\left.{ }^{\mathrm{T}}\right)$.
\end{abstract}

A number of methanogens belonging to hyperthermophilic or thermophilic genera of the order Methanococcales have been obtained from a variety of marine hydrothermal systems (Burgraff et al., 1990; Huber et al., 1982; Jeanthon et al., 1998, 1999a, b; Jones et al., 1983b, 1989; L'Haridon et al., 2003; Stetter, 1996; Takai et al., 2002; Zhao et al., 1988). A number of strains from deep-sea hydrothermal environments have recently been added to the list: Methanocaldococcus jannaschii strain JAL- ${ }^{\mathrm{T}}$, Methanocaldococcus vulcanius strain $\mathrm{M}^{\mathrm{T}}$, Methanocaldococcus fervens strain $\mathrm{AG}^{\mathrm{T}}$ and Methanocaldococcus infernus strain $\mathrm{ME}^{\mathrm{T}}$ were isolated from the East Pacific Rise, Guaymas Basin and the Mid-Atlantic Ridge (MAR) (Jeanthon et al., 1998, 1999a; Jones et al., 1983b, 1989; Zhao et al., 1988); Methanocaldococcus indicus strain SL $43^{\mathrm{T}}$ from the Central Indian

Published online ahead of print on 12 December 2003 as DOI 10.1099/ijs.0.02887-0.

Abbreviations: CIR, Central Indian Ridge; MAR, Mid-Atlantic Ridge.

The GenBank/EMBL/DDBJ accession number for the $16 \mathrm{~S}$ rRNA gene sequence of strain Mc-S- $70^{\top}$ is $\mathrm{AB} 100884$.

Graphs showing the effects of temperature, $\mathrm{pH}$ and $\mathrm{NaCl}$ concentration on growth of Methanotorris formicicus are available as supplementary figures $A, B$ and $C$, respectively, in IJSEM Online.
Ridge (CIR) (L'Haridon et al., 2003); and Methanothermococcus okinawensis strain $\mathrm{IH}^{\mathrm{T}}$ from the Western Pacific Okinawa Trough (Takai et al., 2002). Although physiological and molecular properties have not been described, Jeanthon et al. (1999b) have also succeeded in isolating many hyperthermophilic methanogens potentially belonging to the genus Methanotorris from deep-sea hydrothermal environments in the Guaymas Basin and MAR.

Historically, the systematics of methanococci has been hindered by the absence of information on the reliability of phenotypic characters (Keswani et al., 1996). Recently, Whitman et al. (2001) reclassified the order Methanococcales based on a polyphasic taxonomic characterization. The newly proposed classification fits well with phylogenetic relationships associated with thermophilic behaviour among the order Methanococcales, and the subsequent isolation of a novel species of the genus Methanothermococcus has strengthened the phylogenetic affiliation of members of the genus Methanothermococcus (Takai et al., 2002). However, the genus Methanotorris is still represented by only one species, Methanotorris igneus strain Kol $5^{\mathrm{T}}$, which was isolated from a coastal hydrothermal environment in Iceland (Burggraf et al., 1990). In addition, none of 
the extremely thermophilic members, which are defined as micro-organisms capable of growth above $80^{\circ} \mathrm{C}$ and optimally above $70^{\circ} \mathrm{C}$, has been obtained from any habitat, although many hyperthermophilic or thermophilic entities are listed in the order Methanococcales (L'Haridon et al., 2003; Takai et al., 2002; Whitman et al., 2001). In this study, an extremely thermophilic strain of the genus Methanotorris was isolated from a black smoker chimney at the Kairei field in the CIR.

Samples from a black smoker vent were obtained from the Kairei field, CIR $\left(25^{\circ} 19 \cdot 23^{\prime} \mathrm{S} ; 70^{\circ} 02 \cdot 42^{\prime} \mathrm{E}\right)$, at a depth of $2421 \mathrm{~m}$ by the manned submersible Shinkai 6500 in a dive (dive no. 659) performed in February 2002. The Kairei hydrothermal field in the CIR was discovered by Japanese scientists in 2000 (Hashimoto et al., 2001). A bulk chimney sample with a vent emission temperature of $>250{ }^{\circ} \mathrm{C}$ was brought to the sea surface in a sample box, which is part of the equipment of the Shinkai 6500, and immediately divided into two sections (surface layer of the chimney and vent orifice surface) as described by Takai et al. (2001). The chimney was mainly composed of crystalline or amorphous chalcopyrite. Each of the subsample sections (approx. $10 \mathrm{~g}$ ) was suspended in $20 \mathrm{ml}$ sterilized MJ synthetic sea water (Takai et al., 1999) containing $0.05 \%$ (w/v) sodium sulfide in a $100 \mathrm{ml}$ glass bottle (Schott Glaswerke) and tightly sealed with a butyl rubber cap under a gas phase of $100 \% \mathrm{~N}_{2}$ $(100 \mathrm{kPa})$. These suspended portions of the subsamples were inoculated $(0 \cdot 1 \%$ volume of the medium) onto MMJ medium (Takai et al., 2002) with $5 \mathrm{mM} \mathrm{CaCl}_{2}$ under a gas phase of $80 \% \mathrm{H}_{2}$ and $20 \% \mathrm{CO}_{2}(300 \mathrm{kPa})$. The cultures were incubated at 70 and $85^{\circ} \mathrm{C}$ in dry ovens onboard.

Growth of hyperthermophilic or thermophilic microorganisms was observed in MMJ medium with $5 \mathrm{mM}$ $\mathrm{CaCl}_{2}$ after 2 days incubation at both 70 and $85^{\circ} \mathrm{C}$. Based on DAPI (4',6-diamidino-2-phenylindole)-stained direct cell counting of the subsamples (Porter \& Feig, 1980), the chimney surface layer contained $8.9 \times 10^{7}$ cells ( $\mathrm{g}$ wet weight $)^{-1}$, whereas the vent orifice surface had $1.0 \times 10^{5}$ cells $(\mathrm{g} \text { wet weight })^{-1}$. These results were similar to previously demonstrated results on a black smoker chimney structure from the Manus Basin deep-sea hydrothermal field (Takai et al., 2001). All enrichment cultures grown at 70 and $85^{\circ} \mathrm{C}$ contained highly motile or non-motile irregular cocci. Since these irregular cocci had autofluorescence under UVand blue-excitation by epifluorescence microscopy, the hyperthermophiles or thermophiles were probably methanogens, most likely members of the order Methanococcales. Characterization of the gas phase after growth using a GC (Micro GC CP2002; GL Sciences) revealed that methanogenesis occurred in all enrichment cultures grown at 70 and $85^{\circ} \mathrm{C}$. Pure cultures were obtained using the dilution-toextinction technique at 70 or $85^{\circ} \mathrm{C}$ with the same medium used for the enrichment (Takai \& Horikoshi, 2000). At least five series of dilution-to-extinction purifications were performed. The partial sequence of the $16 \mathrm{~S}$ rRNA gene from each of the isolates was determined and used for sequence similarity analysis as described previously (Takai et al., 2001). One strain, designated Mc-S- $70^{\mathrm{T}}$, was characterized further. The purity of the isolate was confirmed routinely by microscopic examination and by repeated partial sequencing of the $16 \mathrm{~S}$ rRNA gene using several PCR primers (Lane, 1985). Potential contamination of heterotrophic thermophiles was also tested using media for strict heterotrophs such as MJYP and MJYPS (Takai et al., 2000).

Cells were routinely observed under a phase-contrast Olympus BX51 microscope with the SPOT RT Slider CCD camera system (Diagnostic Instruments). Transmission electron microscopy of negatively stained cells and thin sections of cells was carried out as described by Zillig et al. (1990). Cells grown in MMJ medium supplemented with $5 \mathrm{mM} \mathrm{CaCl}_{2}$ at $70{ }^{\circ} \mathrm{C}$ in the mid-exponential phase of growth were negatively stained with $2 \%(\mathrm{w} / \mathrm{v})$ uranyl acetate and observed under a JEOL JEM-1210 electron microscope at an accelerating voltage of $120 \mathrm{kV}$. Cells of strain Mc-S- $70^{\mathrm{T}}$ were Gram-negative, irregular cocci, which were about $0 \cdot 8-1 \cdot 5 \mu \mathrm{m}$ diameter in the exponential growth phase (Fig. 1a, b). Motility was not evident in laboratory cultures, although several thin, long flagella were observed by electron microscopy (Fig. 1a). These morphological features were quite similar to those of Methanotorris igneus strain Kol $5^{\mathrm{T}}$ (Burggraf et al., 1990). In static culture with MMJ medium supplemented with $5 \mathrm{mM}$

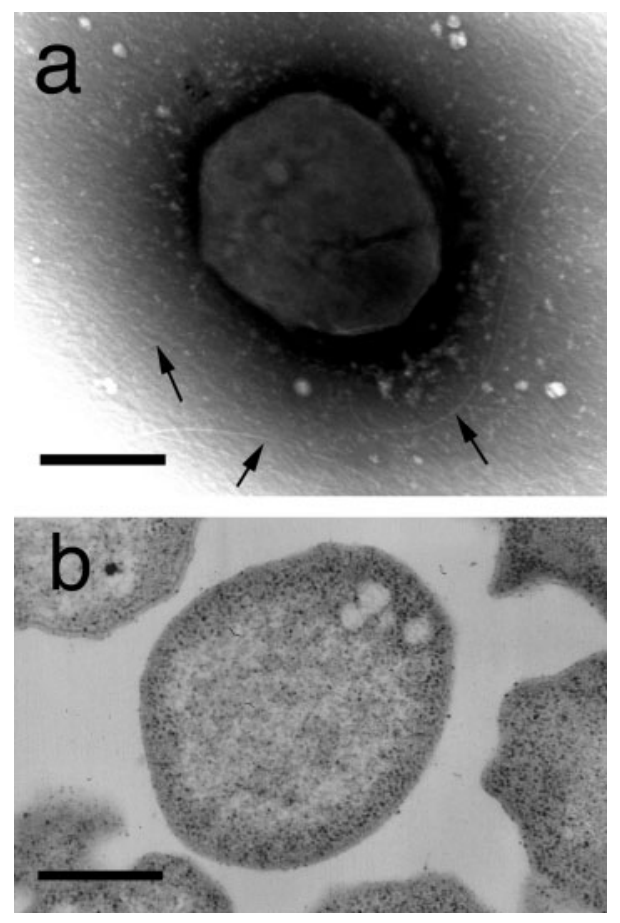

Fig. 1. Electron micrograph of negatively stained cells (a) and thin sections (b) of strain $\mathrm{Mc}-\mathrm{S}-70^{\top}$ in the mid-exponential phase of growth. A few thin, long flagella (arrow heads) were observed (a). The cell envelope structure of the thin section shows that strain Mc-S- $70^{\top}$ is Gram-negative. Bars, $500 \mathrm{~nm}$. 
$\mathrm{CaCl}_{2}$, strain $\mathrm{Mc}-\mathrm{S}-70^{\mathrm{T}}$ grew as an aggregate without causing turbidity in the liquid. Formation of an aggregate in static culture might be associated with non-motility of strain Mc$\mathrm{S}-70^{\mathrm{T}}$. This was a distinctive growth characteristic, which was not common among other Methanococcales strains tested (Methanocaldococcus jannaschii strain JAL-1 ${ }^{\mathrm{T}}$, Methanotorris igneus strain $\mathrm{Kol}^{\mathrm{T}}$, Methanothermococcus okinawensis strain $\mathrm{IH} 1^{\mathrm{T}}$, Methanothermococcus thermolithotrophicus strain $\mathrm{SN}-1^{\mathrm{T}}$ and Methanococcus maripaludis strain $\left.\mathrm{JJ}^{\mathrm{T}}\right)$. Methanocaldococcus jannaschii strain JAL- ${ }^{\mathrm{T}} \quad\left(=\mathrm{JCM} 10045^{\mathrm{T}}\right)$, Methanothermococcus thermolithotrophicus strain $\mathrm{SN}-1^{\mathrm{T}}$ $\left(=\mathrm{JCM} 10549^{\mathrm{T}}\right)$ and Methanococcus maripaludis strain $\mathrm{JJ}^{\mathrm{T}}$ $\left(=\right.$ JCM $\left.10722^{\mathrm{T}}\right)$ were obtained from the Japan Collection of Microorganisms (Wako, Japan) and Methanotorris igneus strain Kol $5^{\mathrm{T}}\left(=\mathrm{DSM} 5666^{\mathrm{T}}\right)$ was purchased from the Deutsche Sammlung von Mikrooganismen und Zellkulturen (Braunschweig, Germany). All strains were cultivated under optimal conditions, as described previously (Burggraf et al., 1990; Huber et al., 1982; Jones et al., 1983a, b; Takai et al., 2002).

Strain Mc-S $-70^{\mathrm{T}}$ was routinely cultivated in MMJ medium supplemented with $5 \mathrm{mM} \mathrm{CaCl}_{2}$. Growth was measured by direct cell counting after staining with DAPI (Porter \& Feig, 1980) using an Olympus BX51 microscope with the SPOT RT Slider CCD camera system. All experiments described below were conducted in duplicate.

Strain Mc-S- $70^{\mathrm{T}}$ grew only under strictly anaerobic culture conditions and was strongly sensitive to oxygen. It was an autotrophic methanogen utilizing hydrogen and carbon dioxide as the sole energy and carbon sources. During growth, hydrogen and carbon dioxide levels in the headspace gas decreased and methane was produced (approx. 100 p.p.m. $\mathrm{H}_{2}, 3000$ p.p.m. $\mathrm{CO}_{2}$ and $95 \% \mathrm{CH}_{4}$ in the gas phase after 2 days incubation). The maximum cell yield in the presence of $\mathrm{H}_{2}$ and $\mathrm{CO}_{2}$ in MMJ medium with $5 \mathrm{mM}$ $\mathrm{CaCl}_{2}$ was $5 \cdot 0 \times 10^{8}$ cells $\mathrm{ml}^{-1}$. If the concentration of calcium ions in MMJ medium was decreased to $0.2 \mathrm{mM}$, the maximum cell yield was reduced to $7 \cdot 0 \times 10^{7}$ cells $\mathrm{ml}^{-1}$. $\mathrm{Mc}-\mathrm{S}-70^{\mathrm{T}}$ grew on formate $(10 \mathrm{mM})$ in the absence of $\mathrm{H}_{2}\left(8.0 \times 10^{7}\right.$ cells $\mathrm{ml}^{-1}$ after 2 days incubation $)$ in MMJ medium with $5 \mathrm{mM} \mathrm{CaCl}_{2}$, indicating that strain Mc-S- $70^{\mathrm{T}}$ was able to utilize formate as an alternative energy source. Acetate $(20 \mathrm{mM})$, methanol $(0.05 \%, \mathrm{v} / \mathrm{v})$, ethanol $(0 \cdot 05 \%, \mathrm{v} / \mathrm{v})$, dimethyl sulfide $(0 \cdot 2 \% \mathrm{v} / \mathrm{v})$, trimethylamine $(0 \cdot 2 \%, \mathrm{v} / \mathrm{v})$, yeast extract $(0.02 \%, \mathrm{w} / \mathrm{v})$, peptone $(0.02 \%$, $\mathrm{w} / \mathrm{v})$, tryptone $(0.02 \%, \mathrm{w} / \mathrm{v})$, Casamino acids $(0.02 \%, \mathrm{w} / \mathrm{v})$ and an amino acid mixture (containing $0.001 \%$, w/v, each of 20 amino acids) did not replace the growth requirement for $\mathrm{H}_{2}$ or stimulate growth in the presence of $\mathrm{H}_{2}$ and $\mathrm{CO}_{2}$. The following nitrogen sources were used to replace the $5 \mathrm{mM}$ ammonium ion in MMJ medium (with $220 \mathrm{kPa} \mathrm{H}$ and $80 \mathrm{kPa} \mathrm{CO}$ in the gas phase): $5 \mathrm{mM}$ nitrate; $0.5 \mathrm{mM}$ nitrite; and $100 \mathrm{kPa} \mathrm{N}$. Ammonium ion was the most effective nitrogen source: the maximum cell yield obtained was $5 \cdot 0 \times 10^{8}$ cells ml ${ }^{-1}$. Both nitrate and $\mathrm{N}_{2}$ also served as nitrogen sources and their maximum cell yields were

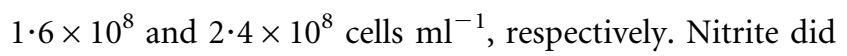
not serve as a nitrogen source. The presence of $10 \mathrm{mM}$ magnetite $\left(\mathrm{Fe}_{3} \mathrm{O}_{4}\right)$ and $10 \mathrm{mM}$ thiosulfate $\left(\mathrm{S}_{2} \mathrm{O}_{3}^{2-}\right)$ had no effect on growth and $3 \%(\mathrm{w} / \mathrm{v})$ elemental sulfur $\left(\mathrm{S}^{0}\right)$ slightly inhibited growth. Selenium, tungsten and vitamin mixture were neither stimulatory nor required for growth. Utilization of formate as a growth substrate and methanogenesis were distinctive features of strain $\mathrm{Mc}-\mathrm{S}-70^{\mathrm{T}}$ compared to Methanotorris igneus strain Kol $5^{\mathrm{T}}$.

The effects of temperature, $\mathrm{pH}$ and $\mathrm{NaCl}$ concentration on growth were tested. With MMJ medium supplemented with $5 \mathrm{mM} \mathrm{CaCl}_{2}$, strain $\mathrm{Mc}-\mathrm{S}-70^{\mathrm{T}}$ grew at $55-83^{\circ} \mathrm{C}$, showing optimal growth at $75^{\circ} \mathrm{C}$; the generation time at $75^{\circ} \mathrm{C}$ and pH 6.7 was about 30 min (see Fig. A, available as supplementary material in IJSEM Online). No growth was observed at 45 or $85^{\circ} \mathrm{C}$. To determine the effect of $\mathrm{pH}$ on growth, the $\mathrm{pH}$ of $\mathrm{MMJ}$ medium containing $5 \mathrm{mM} \mathrm{CaCl}_{2}$ was adjusted to various levels with $10 \mathrm{mM}$ acetate/acetic

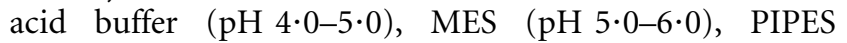

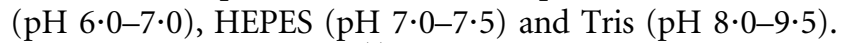
Growth of strain Mc-S- $70^{\mathrm{T}}$ at $70^{\circ} \mathrm{C}$ occurred at $\mathrm{pH} 6 \cdot 0-8 \cdot 5$, with optimum growth at about $\mathrm{pH} 6 \cdot 7$ (see Fig. B, available as supplementary material in IJSEM Online). The $\mathrm{pH}$ was stable during the cultivation period. The effect of $\mathrm{NaCl}$ concentration on growth was determined using MMJ medium with $5 \mathrm{mM} \mathrm{CaCl}{ }_{2}$ containing different amounts of $\mathrm{NaCl}$. Strain Mc-S-70 ${ }^{\mathrm{T}}$ grew in $4-60 \mathrm{~g} \mathrm{NaCl} \mathrm{l}^{-1}$, with optimum growth at $24 \mathrm{~g} \mathrm{NaCl}^{-1}, 70^{\circ} \mathrm{C}$ and pH $6 \cdot 7$ (see Fig. C, available as supplementary material in IJSEM Online). Compared with Methanotorris igneus strain Kol $5^{\mathrm{T}}$, strain Mc-S-70 ${ }^{\mathrm{T}}$ had a lower optimal growth temperature, a lower shifted growth temperature range and a slightly higher shifted $\mathrm{pH}$ range.

The sensitivity of strain Mc-S- $70^{\mathrm{T}}$ to antibiotics such as chloramphenicol $\left(50,100\right.$ and $\left.200 \mu \mathrm{g} \mathrm{ml}^{-1}\right)$, streptomycin $\left(100\right.$ and $\left.200 \mu \mathrm{g} \mathrm{ml}^{-1}\right)$, kanamycin $\left(100\right.$ and $200 \mu \mathrm{g} \mathrm{ml}^{-1}$ ), ampicillin (100 and $200 \mu \mathrm{g} \mathrm{ml}^{-1}$ ) and rifampicin (50 and $100 \mu \mathrm{g} \mathrm{ml}^{-1}$ ) was tested at $70^{\circ} \mathrm{C}$. A simultaneous experiment was performed with Methanotorris igneus strain Kol $5^{\mathrm{T}}$ at $80^{\circ} \mathrm{C}$. Methanotorris igneus strain Kol $5^{\mathrm{T}}$ and strain Mc$\mathrm{S}-70^{\mathrm{T}}$ showed the same antibiotic resistance pattern. Both strains were resistant to streptomycin (up to $200 \mu \mathrm{g} \mathrm{ml}^{-1}$ ), kanamycin (up to $200 \mu \mathrm{g} \mathrm{ml}^{-1}$ ) and rifampicin (up to $\left.50 \mu \mathrm{g} \mathrm{ml}^{-1}\right)$, but sensitive to chloramphenicol $\left(50 \mu \mathrm{g} \mathrm{ml}^{-1}\right)$ and rifampicin $\left(100 \mu \mathrm{g} \mathrm{ml}^{-1}\right)$. Susceptibility to lysis by SDS and a hypotonic solution was tested as described previously (Boone \& Whitman, 1988). Cells of strain Mc-S- $70^{\mathrm{T}}$ lysed with $0 \cdot 1 \%(\mathrm{w} / \mathrm{v})$ SDS solution and hypotonic solutions $\left[10^{-1}\right.$ diluted $\mathrm{MJ}(-\mathrm{N})$ synthetic sea water (Takai et al., 2000) and distilled water].

Hydrocarbon chains in core ether lipids were analysed by a combined method described by Koga et al. (1993) and DeLong et al. (1998). Total lipid was extracted from lyophilized cells of strain Mc-S-70 ${ }^{\mathrm{T}}(50 \mathrm{mg})$ harvested in late-exponential growth phase by the method of Nishihara \& Koga (1987) and Koga et al. (1993). Then, hydrocarbon 
chains were prepared by HI degradation followed by $\mathrm{LiAlH}_{4}$ reduction as described by DeLong et al. (1998). The resulting hydrocarbons were analysed by GLC (model GC-380; GL-Science) equipped with a mass spectrometer (GCMS-QP5050; Shimadzu) at a temperature increasing from 100 to $320^{\circ} \mathrm{C}$ at a rate of $4{ }^{\circ} \mathrm{C} \mathrm{min}{ }^{-1}$. A simultaneous experiment was performed with Methanotorris igneus strain Kol $5^{\mathrm{T}}$, Methanocaldococcus jannaschii strain JAL- ${ }^{\mathrm{T}}$ and Methanothermococcus okinawensis strain $\mathrm{IH}^{\mathrm{T}}$. The hydrocarbon chains of strain Mc-S- $70^{\mathrm{T}}$ were $\mathrm{C}_{20}(76 \cdot 9 \%)$, derived from archaeol and hydroxyarchaeol, and $\mathrm{C}_{40}(23 \cdot 1 \%)$, derived from caldarchaeol and cyclic archaeol. No $\mathrm{C}_{40}$ isoprenoid containing cyclopentane and cyclohexane rings was detected in strain Mc-S-70 ${ }^{\mathrm{T}}$. Compared to hydrocarbons in Methanotorris igneus strain $\mathrm{Kol}^{\mathrm{T}}\left(\mathrm{C}_{20}, 55 \cdot 4 \%\right.$; $\left.\mathrm{C}_{40}, 44 \cdot 6 \%\right)$, Methanocaldococcus jannaschii strain JAL-1 ${ }^{\mathrm{T}}$ $\left(\mathrm{C}_{20}, 19 \cdot 6 \% ; \mathrm{C}_{40}, 80 \cdot 4 \%\right)$ and Methanothermococcus okinawensis strain $\mathrm{IH}^{\mathrm{T}}\left(\mathrm{C}_{20}, 37 \cdot 8 \% ; \mathrm{C}_{40}, 63 \cdot 2 \%\right)$, a lower proportion of $\mathrm{C}_{40}$ isoprenoid was found in strain Mc-S- $70^{\mathrm{T}}$.

Genomic DNA of strain Mc-S-70 ${ }^{\mathrm{T}}$ was prepared as described by Marmur \& Doty (1962). The DNA G+C content was determined by direct analysis of deoxyribonucleotides by HPLC (Tamaoka \& Komagata, 1984). The $\mathrm{G}+\mathrm{C}$ content of the genomic DNA of strain Mc-S-70 ${ }^{\mathrm{T}}$ was $33.3 \mathrm{~mol} \%$, which is slightly higher than that of Methanotorris igneus strain Kol $5^{\mathrm{T}}$ (Table 1).

The $16 \mathrm{~S}$ rRNA gene was amplified by PCR using Arch $21 \mathrm{~F}$ and 1492R primers (DeLong, 1992; Lane, 1985) as described previously (Takai et al., 2002). The nearly complete sequence (1374 bp) of the 16S rRNA gene from strain Mc-S- $70^{\mathrm{T}}$ was directly sequenced from both strands using the dideoxynucleotide chain-termination method with a DNA sequencer model 3100 (Perkin Elmer/Applied Biosystems). The 16S rRNA gene sequence was analysed using the gapped-BLAST search algorithm (Altschul et al., 1997; Benson et al., 1998) and was most closely related $(97 \cdot 8 \%)$ to that of Methanotorris igneus strain Kol $5^{\mathrm{T}}$ (Burggraf et al., 1990). This suggested that strain Mc-S-70 ${ }^{\mathrm{T}}$ belongs to the genus Methanotorris.
The nearly complete sequence was manually realigned to $16 \mathrm{~S}$ rRNA gene data from the Ribosomal Data Project II (Maidak et al., 2000), based on alignments determined using the SEQUENCE ALIGNER program of RDP-II. Phylogenetic analyses were restricted to nucleotide positions that could be unambiguously aligned. Evolutionary distance matrix analysis (using the Kimura two-parameter method, the least-squares distance method and transition/transversion rate of $2 \cdot 0)$ and neighbour-joining analysis were performed using the PHYLIP package (version 3.5; obtained from J. Felsenstein, University of Washington, Seattle, WA, USA) (Fig. 2). Bootstrap analysis was performed to provide confidence estimates for phylogenetic tree topologies. The phylogenetic tree indicated that strain Mc-S $-70^{\mathrm{T}}$ is closely related to Methanotorris igneus strain $\mathrm{Kol}^{\mathrm{T}}$, as determined by sequence similarity analysis (Fig. 2).

DNA-DNA hybridization was carried out between the genomic DNA of strain Mc-S- $70^{\mathrm{T}}$ and Methanotorris igneus strain Kol $5^{\mathrm{T}}$ at $42^{\circ} \mathrm{C}$ for $3 \mathrm{~h}$ and was measured fluorometrically using photobiotin according to the method of Ezaki et al. (1989). The mean hybridization value was $5 \cdot 1 \%$, indicating that strain $\mathrm{Mc}-\mathrm{S}-70^{\mathrm{T}}$ could be genotypically differentiated from the previously described species of the genus Methanotorris.

Strain Mc-S- $70^{\mathrm{T}}$ was isolated from a black smoker chimney of a deep-sea hydrothermal vent at a depth of $2421 \mathrm{~m}$ at the Kairei field, CIR. Phylogenetic analysis indicated that strain Mc-S- $70^{\mathrm{T}}$ is most closely related to Methanotorris igneus strain Kol $5^{\mathrm{T}}$, which was isolated from a coastal hydrothermal environment in Iceland (Burggraf et al., 1990), and was probably a member of the genus Methanotorris. However, many of the physiological characteristics of strain Mc-S- $70^{\mathrm{T}}$ differed from those of Methanotorris igneus strain Kol $5^{\mathrm{T}}$ (Table 1). Strain Mc-S- $70^{\mathrm{T}}$ is the first extreme thermophile found within the order Methanococcales that grows optimally at $75^{\circ} \mathrm{C}$, which is approximately $10^{\circ} \mathrm{C}$ lower than the optimum of Methanotorris igneus strain Kol $5^{\mathrm{T}}$ (Table 1). In addition, Methanotorris igneus strain Kol $5^{\mathrm{T}}$ is known as the most acidiphilic thermophilic methanogen (Wiegel, 2002), having an optimal $\mathrm{pH}$ for growth of $\mathrm{pH} 5 \cdot 7$,

Table 1. Properties that differentiate strains of Methanotorris formicicus and Methanotorris igneus

\begin{tabular}{|lcc|}
\hline Character & Methanotorris formicicus strain Mc-S-70 & ${\text { Methanotorris igneus strain } \mathbf{~ K o l ~} \mathbf{5}^{\mathbf{T}}}^{\mathbf{T}}$ \\
\hline Isolation environment & Deep-sea black smoker chimney, CIR & Coastal hydrothermal system, Iceland \\
Cell diameter $(\mu \mathrm{m})$ & $0 \cdot 8-1 \cdot 5$ & $1 \cdot 0-2 \cdot 0$ \\
Formate as a substrate for methane synthesis & + & - \\
Yeast extract stimulation of growth & $55-83(75)$ & + \\
Temperature range $\left(\right.$ optimum) $\left({ }^{\circ} \mathrm{C}\right)$ & $6 \cdot 0-8 \cdot 5(6 \cdot 7)$ & $45-91(88)$ \\
pH range (optimum) & $0 \cdot 4-6 \cdot 0(2 \cdot 4)$ & $5 \cdot 0-7 \cdot 5(5 \cdot 7)$ \\
NaCl range (optimum) $(\%, \mathrm{w} / \mathrm{v})$ & $33 \cdot 3$ & $0 \cdot 9-5 \cdot 4(1 \cdot 8)$ \\
Genomic DNA G $+\mathrm{C}$ content $(\mathrm{mol} \%)$ & This study & 31 \\
References & & Burggraf et al. $(1990)$; Whitman et al. $(2001)$ \\
\hline
\end{tabular}




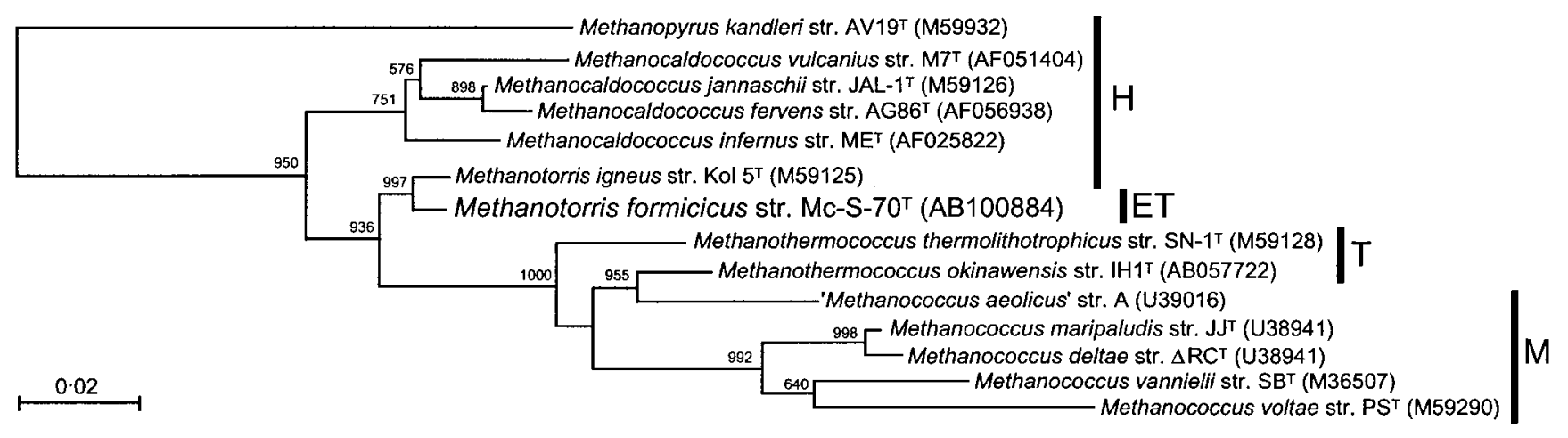

Fig. 2. Phylogenetic tree of representative members of the order Methanococcales inferred from $16 \mathrm{~S}$ rRNA gene sequences by the neighbour-joining method using 1208 homologous sequence positions for each organism. The number at each node represents the bootstrap value (1000 replicates). Bar, 2 substitutions per $100 \mathrm{nt}$. H, Hyperthermophilic; ET, extremely thermophilic; T, thermophilic; M, mesophilic.

whereas strain Mc-S- $70^{\mathrm{T}}$ grows optimally at neutral $\mathrm{pH}$ (Table 1). Another distinctive feature is the utilization of formate as a substrate for growth and methanogenesis in strain $\mathrm{Mc}-\mathrm{S}-70^{\mathrm{T}}$ (Table 1). All the hyperthermophilic members of the order Methanococcales known so far, other than a hyperthermophilic isolate (strain CS-1) from the Guaymas Basin (Jones et al., 1989), are unable to use formate as a sole energy source (Whitman et al., 2001). In sharp contrast, all thermophilic and mesophilic entities of the order Methanococcales can utilize formate as a sole energy source, providing a similar growth yield to $\mathrm{H}_{2}$ (Whitman et al., 2001). In strain Mc-S- $70^{\mathrm{T}}$, formate gives considerably lower growth yield than $\mathrm{H}_{2}$, but can serve as an alternative energy source (Table 1). The extremely thermophilic behaviour and formate utilization of strain Mc-S- $70^{\mathrm{T}}$ are important physiological features that support genetic differentiation between strain Mc-S- $70^{\mathrm{T}}$ and Methanotorris igneus strain $\mathrm{Kol} 5^{\mathrm{T}}$ by DNA-DNA relatedness. These may also represent intermediate traits during evolution of the order Methanococcales from hyperthermophile to mesophile. On the basis of these physiological and genetic properties, it is proposed that the isolate is classified as a novel species of the genus Methanotorris, Methanotorris formicicus sp. nov., with Mc-S- $70^{\mathrm{T}}$ as the type strain.

\section{Description of Methanotorris formicicus sp. nov.}

Methanotorris formicicus (for.mi' ci.cus. N.L. neut. n. acidum formicum formic acid; N.L. neut. adj. formicicus pertaining to formic acid).

Irregular coccus, mean diameter of $0 \cdot 8-1 \cdot 5 \mu \mathrm{m}$. Cells occur singly or in pairs. Non-motile, but with a few thin, long flagella, which are easily removed from the cell. Strictly anaerobic and obligately methanogenic. The temperature range for growth is $55-83^{\circ} \mathrm{C}$ (optimum of $75^{\circ} \mathrm{C}$ ). The $\mathrm{pH}$ range for growth is $\mathrm{pH} 6 \cdot 0-8 \cdot 5$ (optimum of $\mathrm{pH} 6 \cdot 7$ ). $\mathrm{NaCl}$ is required for growth, which occurs in $4-60 \mathrm{~g} \mathrm{NaCl} \mathrm{l}^{-1}$ (optimum growth at $24 \mathrm{~g} \mathrm{l}^{-1}$ ). Grows using molecular hydrogen or formate as an electron donor and carbon dioxide as an electron acceptor and a carbon source. Ammonium, molecular nitrogen and nitrate serve as nitrogen sources. Vitamins, selenium, tungsten, magnetite $\left(\mathrm{Fe}_{3} \mathrm{O}_{4}\right)$ and thiosulfate do not stimulate growth. Resistant to ampicillin $\left(200 \mu \mathrm{g} \mathrm{ml}^{-1}\right)$, kanamycin $\left(200 \mu \mathrm{g} \mathrm{ml}^{-1}\right)$, rifampicin $\left(50 \mu \mathrm{g} \mathrm{ml}^{-1}\right)$ and streptomycin $\left(200 \mu \mathrm{g} \mathrm{ml}^{-1}\right)$, but sensitive to chloramphenicol $\left(50 \mu \mathrm{g} \mathrm{ml}^{-1}\right)$ and rifampicin $\left(100 \mu \mathrm{g} \mathrm{ml}^{-1}\right)$. Susceptible to lysis by $0 \cdot 1 \%(\mathrm{w} / \mathrm{v})$ SDS solution and hypotonic solutions. Major hydrocarbon chains of core lipids are $\mathrm{C}_{20}(76 \cdot 9 \%)$ and $\mathrm{C}_{40}(23 \cdot 1 \%) .16 \mathrm{~S}$ rRNA gene sequence exhibits $97 \cdot 8 \%$ similarity to that of Methanotorris igneus strain Kol $5^{\mathrm{T}}$. DNA-DNA relatedness to Methanotorris igneus strain $\mathrm{Kol} 5^{\mathrm{T}}$ is low.

The type strain is Mc-S- $70^{\mathrm{T}}\left(=\right.$ JCM $11930^{\mathrm{T}}=$ ATCC BAA$687^{\mathrm{T}}$ ), isolated from a black smoker chimney in the Kairei field, Central Indian Ridge, Indian Ocean. Its genomic DNA $\mathrm{G}+\mathrm{C}$ content is $33 \cdot 3 \%$ (HPLC method).

\section{Acknowledgements}

We would like to thank Dr K. Uematsu for assistance in preparing electron micrographs. We are very grateful to the $R / V$ Yokosuka crews and the Shinkai 6500 operation team for helping us to obtain deep-sea hydrothermal vent samples.

\section{References}

Altschul, S. F., Madden, T. L., Schaffer, A. A., Zhang, J., Zhang, Z., Miller, W. \& Lipman, D. J. (1997). Gapped BLAST and PSI-BLAST: a new generation of protein database search programs. Nucleic Acids Res 25, 3389-3402.

Benson, D. A., Boguski, M. S., Lipman, D. J., Ostell, J. \& Ouellette, B. F. F. (1998). GenBank. Nucleic Acids Res 26, 1-7.

Boone, D. R. \& Whitman, W. B. (1988). Proposal of minimal standards for describing new taxa of methanogenic bacteria. Int J Syst Bacteriol 38, 212-219.

Burggraf, S., Fricke, H., Neuner, A., Kristjansson, J. K., Rouvier, P., Mandelco, L., Woese, C. R. \& Stetter, K. O. (1990). Methanococcus igneus sp. nov., a novel hyperthermophilic methanogen from a 
shallow submarine hydrothermal system. Syst Appl Microbiol 13, 263-269.

DeLong, E. F. (1992). Archaea in coastal marine environments. Proc Natl Acad Sci U S A 89, 5685-5689.

DeLong, E. F., King, L. L., Massana, R., Cittone, H., Murray, A., Schleper, C. \& Wakeham, G. (1998). Dibiphytanyl ether lipids in nonthermophilic crenarchaeotes. Appl Environ Microbiol 64, 1133-1138.

Ezaki, T., Hashimoto, Y. \& Yabuuchi, E. (1989). Fluorometric deoxyribonucleic acid-deoxyribonucleic acid hybridization in microdilution wells as an alternative to membrane filter hybridization in which radioisotopes are used to determine genetic relatedness among bacterial strains. Int J Syst Bacteriol 39, 224-229.

Hashimoto, J., Ohta, S., Gamo, T. \& 7 other authors (2001). First hydrothermal vent communities from the Indian Ocean discovered. Zool Sci 18, 717-721.

Huber, H., Thomm, M., König, H., Thies, G. \& Stetter, K. O. (1982). Methanococcus thermolithotrophicus, a novel thermophilic lithotrophic methanogen. Arch Microbiol 132, 47-50.

Jeanthon, C., L'Haridon, S., Reysenbach, A. L., Vernet, M., Messner, P., Sleytr, U. B. \& Prieur, D. (1998). Methanococcus infernus sp. nov., a novel hyperthermophilic lithotrophic methanogen isolated from a deep-sea hydrothermal vent. Int J Syst Bacteriol 48, 913-919.

Jeanthon, C., L'Haridon, S., Reysenbach, A.-L., Corre, E., Vernet, M., Messner, P., Sleytr, U. B. \& Prieur, D. (1999a). Methanococcus vulcanius sp. nov., a novel hyperthermophilic methanogen isolated from East Pacific Rise, and identification of Methanococcus sp. DSM $4213^{\mathrm{T}}$ as Methanococcus fervens sp. nov. Int J Syst Bacteriol 49, 583-589.

Jeanthon, C., L'Haridon, S., Pradel, N. \& Prieur, D. (1999b). Rapid identification of hyperthermophilic methanococci isolated from deep-sea hydrothermal vents. Int J Syst Bacteriol 49, 591-594.

Jones, W. J., Paynter, M. J. B. \& Gupta, R. (1983a). Characterization of Methanococcus maripaludis sp. nov., a new methanogen isolated from salt marsh sediment. Arch Microbiol 135, 91-97.

Jones, W. J., Leigh, J. A., Mayer, F., Woese, C. R. \& Wolfe, R. S. (1983b). Methanococcus jannaschii sp. nov., an extremely thermophilic methanogen from a submarine hydrothermal vent. Arch Microbiol 136, 254-261.

Jones, W. J., Stugard, C. E. \& Jannasch, H. W. (1989). Comparison of thermophilic methanogens from submarine hydrothermal vents. Arch Microbiol 151, 314-318.

Keswani, J., Orkand, S., Premachandran, U., Mandelco, L., Franklin, M. J. \& Whitman, W. B. (1996). Phylogeny and taxonomy of mesophilic Methanococcus spp. and comparison of rRNA, DNA hybridization, and phenotypic methods. Int J Syst Bacteriol 46, 727-735.

Koga, Y., Akagawa-Matsushita, M., Ohga, M. \& Nishihara, M. (1993). Taxonomic significance of the distribution of component parts of polar ether lipids in methanogens. Syst Appl Microbiol 16, 342-351.

Lane, D. J. (1991). 16S/23S rRNA sequencing. In Nucleic Acid Techniques in Bacterial Systematics, pp. 115-175. Edited by E. Stackebrandt \& M. Goodfellow. Chichester: John Wiley.
L'Haridon, S., Reysenbach, A.-L., Banta, A., Messner, P., Schumann, P., Stackebrandt, E. \& Jeanthon, C. (2003). Methanocaldococcus indicus sp. nov., a novel hyperthermophilic methanogen isolated from the Central Indian Ridge. Int J Syst Evol Microbiol 53, 1931-1935.

Maidak, B. L., Cole, J. R., Lilburn, T. G. \& 9 other authors (2000), The RDP (Ribosomal Database Project) continues. Nucleic Acids Res 28, 173-174.

Marmur, J. \& Doty, P. (1962). Determination of the base composition of deoxyribonucleic acid from its thermal denaturation temperature. J Mol Biol 4, 109-118.

Nishihara, M. \& Koga, Y. (1987). Extraction and composition of polar lipids from the archaebacterium, Methanobacterium thermoautotrophicum: effective extraction of tetraether lipids by an acidified solvent. J Biochem Tokyo 101, 997-1005.

Porter, K. G. \& Feig, Y. S. (1980). The use of DAPI for identifying and counting microflora. Limnol Oceanogr 25, 943-948.

Stetter, K. O. (1996). Hyperthermophilic procaryotes. FEMS Microbiol Rev 18, 149-158.

Takai, K. \& Horikoshi, K. (2000). Thermosipho japonicus sp. nov., an extremely thermophilic bacterium isolated from a deep-sea hydrothermal vent in Japan. Extremophiles 4, 9-17.

Takai, K., Inoue, A. \& Horikoshi, K. (1999). Thermaerobacter marianensis gen. nov., sp. nov., an aerobic extremely thermophilic marine bacterium from the $11000 \mathrm{~m}$ deep Mariana Trench. Int J Syst Bacteriol 49, 619-628.

Takai, K., Sugai, A., Itoh, T. \& Horikoshi, K. (2000). Palaeococcus ferrophilus gen. nov., sp. nov., a barophilic, hyperthermophilic archaeon from a deep-sea hydrothermal vent chimney. Int J Syst Evol Microbiol 50, 489-500.

Takai, K., Komatsu, T., Inagaki, F. \& Horikoshi, K. (2001). Distribution of archaea in a black smoker chimney structure. Appl Environ Microbiol 67, 3618-3629.

Takai, K., Inoue, A. \& Horikoshi, K. (2002). Methanothermococcus okinawensis sp. nov., a thermophilic, methane-producing archaeon isolated from a Western Pacific deep-sea hydrothermal vent system. Int J Syst Evol Microbiol 52, 1089-1095.

Tamaoka, J. \& Komagata, K. (1984). Determination of DNA base composition by reversed-phase high-performance liquid chromatography. FEMS Microbiol Lett 25, 125-128.

Whitman, W. B., Boone, D. R. \& Koga, Y. (2001). Order Methanococcales. In Bergey's Manual of Systematic Bacteriology, 2nd edn, vol. 1, pp. 236-246. Edited by D. R. Boone, R. W. Castenholz \& G. Garrity. Berlin/Heidelberg, Germany: Springer.

Wiegel, J. (2002). Thermophiles: anaerobic alkalithermophiles. In Encyclopedia of Environmental Microbiology, pp. 3127-3140. Edited by G. Bitton. New York: Wiley.

Zhao, H., Wood, A. G., Widdel, F. \& Bryant, M. P. (1988). An extremely thermophilic Methanococcus from a deep-sea hydrothermal vent and its plasmid. Arch Microbiol 150, 178-183.

Zillig, W., Holz, I., Janekovic, D. \& 7 other authors (1990). Hyperthermus butylicus, a hyperthermophilic sulfur-reducing archaebacterium that ferments peptides. J Bacteriol 172, 3959-3965. 